VOLOSOVYCH Svitlana,

Doctor of Economics, Professor, Professor at the Department of Finance

Kyiv National University of Trade and Economics

19, Kyoto str., Kyiv, 02156, Ukraine

E-mail:volosovich_sv@ukr.net

ORCID: https://orcid.org/0000-0003-3143-7582
BARANIUK Yuriy,

Postgraduate student at the Department of Finance

Kyiv National University of Trade and Economics 19, Kyoto str., Kyiv, 02156, Ukraine

E-mail: baraniukyurii@gmail.com ORCID: https://orcid.org/0000-0003-1289-2248

\title{
BLOCKCHAIN TECHNOLOGY
}

\section{IN THE FINANCIAL ECOSYSTEM}

The relationship between the development of financial technologies and the formation of the financial ecosystem has been investigated. It is proposed to divide the properties of the financial ecosystem into general and specific ones. The definition of the financial ecosystem has been clarified on the basis of identification of the institutional, functional and sectoral approaches to its understanding. The signs of classification of blockchains in the financial sphere are systematized.

Keywords: financial ecosystem, financial technologies, blockchain technology, smart contract.

Волосович С., Баранюк Ю. Технология блокчейн в финансовой экосистеме. Исследована взаимосвязь между развитием финансовых технологий и формированием финансовой экосистемы. Предложено разделить свойства финансовой экосистемы на общие и специфические. Уточнена дефиниция финансовой экосистемы на основе выделения институциионального, функционального и отраслевого подходов кее пониманию. Систематизированы признаки классификации блокчейнов в финансовой сфере.

Ключевые слова: финансовая экосистема, финансовые технологии, технология блокчейн, смарт-контракт.

Background. The development of technological innovations and the economy of consumption have led to powerful transformations of both national and global financial systems. It initiated the formation of financial ecosystems, closely linked to the various financial technology tools that unite all its participants. Financial ecosystems are transformed by the impact of financial technology development. The emergence of accessible, fast and convenient financial services, the simplification of tax administration, public

(C) Volosovych S., Baraniuk Y., 2019 
procurement, the receipt of social security based on financial technologies enhance the processes of decentralization of financial systems and create the basis for transparency of financial transactions of economic entities, households and the state. One of the financial technology tools that provide it is blockchain technology.

Analysis of recent research and publications. Financial systems are subject to transformations, which are the characteristic feature of the economic systems of many developed countries in the world [1]. Substantial transformations of the structure of the financial system are due to the liberalization of financial legislation, the invention of new financial instruments and the gradual universalization of banking activities [2].

In foreign scientific literature, the issues of the functioning of financial ecosystems are explored by I. Lee and Y. Shin [3], K. Swenson, J. Yudesen and J. Webb [4], C. Bose [5], Z. Posser [6] and others. The most of works of domestic scientists concern the analysis of only certain types of financial ecosystems, in particular, cashless payments in the agricultural sector [7], banking ecosystem [8]. All publications, without exception, emphasize that financial technologies are the basis for the existence of financial ecosystems, and blockchain is its important tool. The works of J. Chen, K. Belavitis [9], J. Mulhol [10], O. Baranov [11] and others are devoted to some problems of the use of blockchain technology in the financial sphere. However, despite the high level of existing theoretical developments, the questions on the essence of financial ecosystems and the role of blockchain technology in their transformations require further research.

The aim of the article is to determine the priorities for the use of blockchain technology in ensuring the functioning of financial ecosystems.

Materials and methods. The theoretical and methodological basis for writing the article were the works of domestic and foreign scientists on the functioning of financial ecosystems, the role of financial technology tools in its provision, including blockchain technology. The study was conducted using the methods of theoretical generalization, comparative analysis and synthesis, which allowed clarifying the definition of financial ecosystem, identifying its specific properties and systematizing the features of blockchain classification in the financial sphere.

Results. The term "ecosystem" was originated to describe phenomena and processes occurring in the natural environment, but nowadays it has become widely used in other spheres, in particular, in the functioning of financial systems. There are institutional, functional and sectoral approaches to understanding financial ecosystems. The institutional approach involves an emphasis on the composition of ecosystem participants. So, I. Lee and Y. Shin include technology developers, government agencies and regulators; private and corporate financial clients; traditional financial institutions to the financial ecosystem [3]. K. Swenson, J. Yudesen and J. Webb add another compo- 
nent to these participants - FinTech startups [4]. This approach is also supported by the National Bank of Ukraine. In the Strategy of the National Bank of Ukraine, the financial ecosystem refers to the set of participants in the financial market and other parties that at the same time interact on terms of cooperation and competition in order to create and provide financial products and services [12].

Within the functional approach, the team of authors considers the financial ecosystem as a technology platform aimed at digitalization of the financial market, which includes four areas: financial capital, consumer preferences when receiving financial services, Internet of things, financial technologies [13, p. 126-129]. The Internet of things is a financial technology tool, and it is inappropriate to include it as a separate area of the financial ecosystem. As a result, the financial ecosystem is identified with financial technologies [13, p. 29].

The sectoral approach assumes that its supporters understand only some of its subsystems under the financial ecosystem, in particular, the cashless payments subsystem in the agricultural sector [7], the banking ecosystem [8].

The financial ecosystem is characterized by general and specific properties of the systems.

Common properties include:

emergence implies that due to the interaction of individual components, new properties, that characterize the system, emerge;

totality is the sum of properties of each subsystem, that is, it is about the presence of the aggregate properties;

heterogeneity is that the system cannot consist of completely identical elements.

The specific properties of the financial ecosystem include:

adaptability, that is, functioning based on the use of financial technology tools, in particular artificial intelligence, big data, the Internet, blockchain, cryptography, biometrics;

decentralization, which implies a diminishing role of financial intermediaries in the markets;

client orientation, which is conditioned by the increasing role of the consumption economy in modern society;

inclusivity based on increased consumer access to financial services and citizen participation in budgeting;

stability, which implies the security of financial transactions, on the one hand, and crisis prevention or minimization of its consequences, on the other.

The financial ecosystem is a collection of traditional financial intermediaries, FinTech companies, FinTech startups, incubators, accelerators, regulators, business entities, individuals, public financial institutions, educational institutions which interact through the use of financial technology instruments that maximize consumer inclusivity in the financial services market and transparency of public finances.

ISSN 1727-9313. HERALD OF KNUTE. 2019. 
In the ecosystem, each institution seeks to diversify data by managing partnerships with competitors that can be a source of strategic and operational risks $[14$, p. 25]. For the financial ecosystem to function effectively, it is important to ensure the transparency of relationships between all participants. This is to some extent facilitated by blockchain technology. In 2015, the World Economic Forum in Davos stated that blockchain is a new technology that eliminates the need for third parties to ensure confidence in financial, contractual and electoral actions [15]. As Baranov notes, blockchain can establish trust by examining the identity and potential of any counterparty through a combination of past transaction history (by blockchain), reputation indices based on generalized reviews and other socio-economic indicators [11].

The volume of global investments in blockchain technology during 2015-2018 tends to grow amid an increase in its share in global investments in FinTech (figure 1).

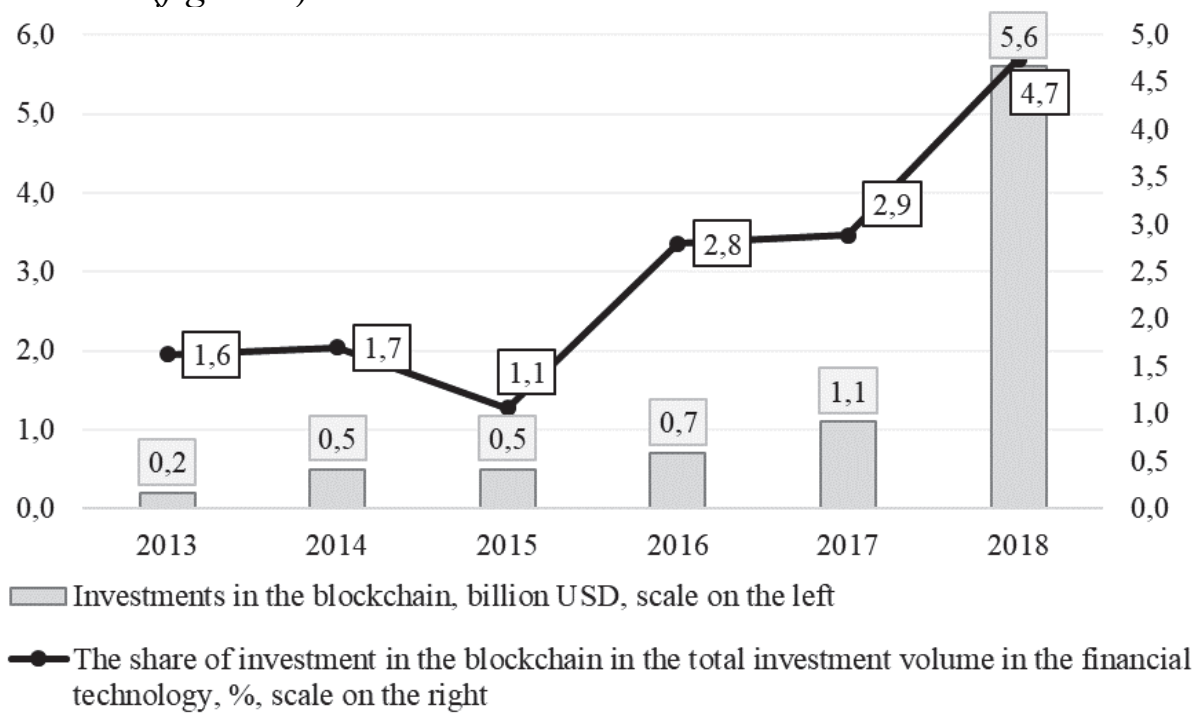

Figure 1. Global investments in blockchain for 2013-2018

Source: constructed by the authors according to the materials [16-18].

According to research company International Data Corporation, China will invest up to USD 2 billion in the development of blockchain companies by 2023 [19]. Since 2015, the US Department of Homeland Security has provided USD 800,000 to Silicon Valley tech startups to develop blockchain solutions aimed at improving the security of the country [20]. At the same time, in the world during 2013-2018, the average annual growth in the number of vacancies in the blockchain industry was $139 \%$, and as of the end of May 2019, 2300 vacancies were opened [21].

There are different approaches to blockchain classification now. It is proposed to classify blockchains in the financial ecosystem by participants, level of centralization, generations and fields of application. 
By participants blockchain are divided into:

public, providing wide open access for users who have equal rights and can perform basic functions: transaction validation, cryptocurrency transfer, access to database records. Examples of such blockchains are Bitcoin, Bitcoin Cash, Litecoin. At the same time, there are public blockchains with different levels of permissions, where there are restrictions on the transparency of transactions and the ability to perform certain functions by users, in particular transaction validation. For example, some BitShares users have the right to be validators or to vote, while others can only see the results of their activities. In the first case, public blockchain is decentralized and used by its participants to exchange cryptocurrency and enter into agreements based on smart contracts. In the second case, blockchain has signs of centralization and is used by corporate networks;

private, which has limited access for users to registry entries, within which they may have the same rights as in a public blockchain. Its example is the Mijin platform. The operation of private blockchains can speed up the transaction process and hide it from third parties. Private blockchain makes it easy to find the right information due to a small number of transaction records. This kind of blockchain can be both centralized and decentralized;

hybrid, which is a new concept that allows you to connect existing blockchain networks with additional blockchains. For example, the Ardor platform has a test network that is identical to the core network. It enables users to refine their skills to avoid possible mistakes and failures while working on the core network.

By the level of centralization, blockchains are divided into decentrallized, where all users can perform the transaction validation function, and centralized, where this function is performed by a specific person.

There are three generations of blockchain in the genesis of blockchain technology. Blockchain 1.0 was created in 2009 on the basis of the new principle of registration of transactions with the advent of bitcoin. The second stage of blockchain development is related to the development of smart contracts by Ethereum company in 2013, which allow them to be executed automatically under the conditions specified therein, which prevents third parties from interfering and reduces costs. The next phase - Blockchain 3.0, started in 2017 with the development of more productive technologies, including Cosmos, DFINITY and EOS.

By area of application in the financial system, blockchains are divided into those used in the financial services market, in the sphere of public finance, business environment and households (figure 2).

It follows from figure 2 that blockchain is most commonly used in the financial services market and in public finance. The table shows the possibilities of using the blockchain by individual entities of the financial ecosystem.

ISSN 1727-9313. HERALD OF KNUTE. 2019. 
According to the Tax Service of the Chinese city of Shenzhen, from August 2018 to November 2019, the number of electronic invoices in this technology center in the field of finance, insurance, retail, restaurant and hotel business, written using blockchain, exceeded 10 million in the amount of 1 billion USD against the background that more than 7.6 thousand companies have accessed this system [26]. During 2018, the volume of active loans provided with the help of decentralized lending protocols increased by $1.083 \%$ [27].

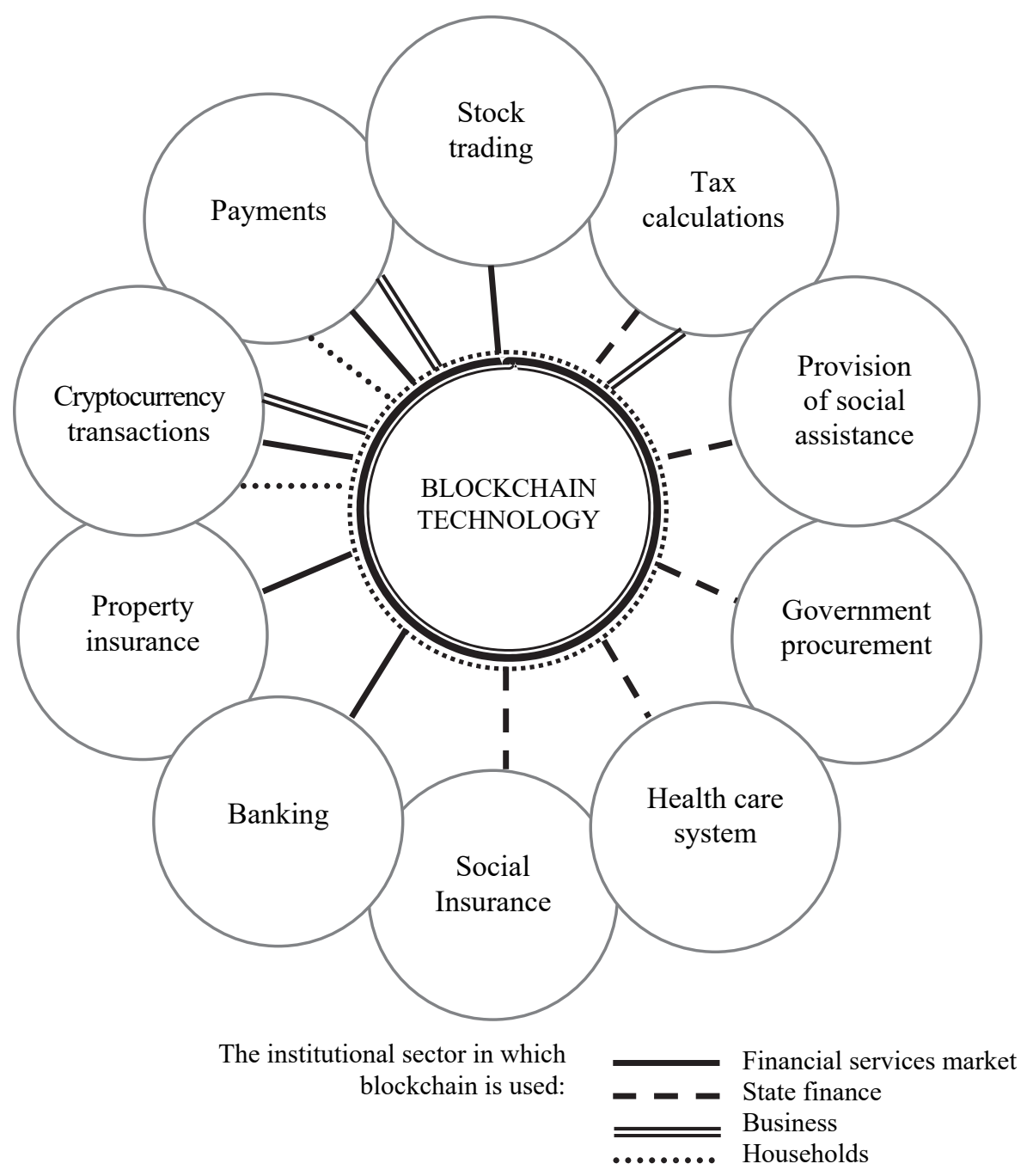

Figure 2. Application of blockchain technology in the financial sphere

Source: created by the authors.

The second largest stock exchange in the world, the New York Stock Exchange Nasdaq, has added the Decentralised Finance Index (DEFX) that monitors the effectiveness of blockchain projects after the inclusion of Bitcoin and Ethereum indices in early 2019 to exchange list [28]. This index has already been applied previously by the London brokerage company Exante. The Nasdaq Global Index DataSMS (GIDS) provides real-time 
information on Bitcoin, Ethereum and Ripple exchange rate through Bitcoin Liquid Index (BLX), Ethereum Liquid Index (ELX) and XRP Liquid Index $(X R P L X)$. With the help of blockchain technology, the Depository Trust and Clearing Corporation (DCTT) maintains a daily record of 90 million financial transactions with global securities amounting to 48 trillion USD [29].

Table

\section{Opportunities for individual entities of the financial ecosystem to apply blockchain}

\begin{tabular}{|c|c|c|c|c|c|c|c|c|}
\hline \multirow[b]{2}{*}{ Scope } & \multicolumn{8}{|c|}{ Subjects of the financial ecosystem } \\
\hline & 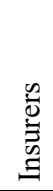 & $\frac{n}{\tilde{E}}$ & 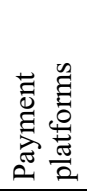 & 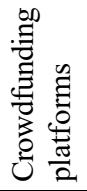 & 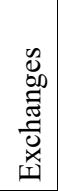 & 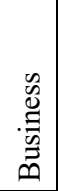 & 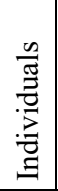 & 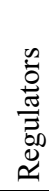 \\
\hline Process automation & + & + & + & + & + & + & & + \\
\hline $\begin{array}{l}\text { Creation and monitoring of insurance } \\
\text { (payment, credit) history, ownership } \\
\text { transfer history, delivery of goods }\end{array}$ & + & + & + & + & + & + & & + \\
\hline $\begin{array}{l}\text { Shortening of payment terms, identifying } \\
\text { the connection between transactions }\end{array}$ & + & + & + & + & + & + & + & + \\
\hline $\begin{array}{l}\text { Ensuring receipt of information } \\
\text { from state authorities }\end{array}$ & + & + & & + & & + & + & \\
\hline Instant fixation of insurance events & + & & & & & + & + & \\
\hline Conclusion of contracts online & + & + & + & + & + & + & + & \\
\hline Smart contracts conclusion & + & & & & + & + & + & \\
\hline Confirmation of identity & + & + & + & + & + & + & + & \\
\hline Preliminary risk assessment & + & + & + & + & + & + & + & + \\
\hline $\begin{array}{l}\text { Interaction with other entities } \\
\text { of the financial ecosystem }\end{array}$ & + & + & + & + & + & + & + & + \\
\hline $\begin{array}{l}\text { Transparency of settlement of clients' } \\
\text { claims against insurers }\end{array}$ & + & & & & & + & + & \\
\hline $\begin{array}{l}\text { The prevention of money laundering } \\
\text { and financing of terrorism }\end{array}$ & + & + & + & + & & & & + \\
\hline
\end{tabular}

Source: constructed by authors according to the materials $[10 ; 11 ; 22-25]$.

According to the forecasts of the World Economic Forum, 10\% of the world gross product will be stored on blockchain or related technologies by 2025-2027 [15]. In 2018, the World Trade Organization stressed that international trade volumes would increase by 1 trillion USD by 2030 through the facilitation of trade financing and international shipping, logistics automation and customs clearance [30].

Consortia are now being set up in different regions of the world to explore the possibilities of using blockchain in different areas. In 2014, it was established the R3 CEV LLC blockchain consortium with a location in New York to develop blockchain applications in financial systems. In 2016, in Luxembourg, BIL, BNP Paribas, CACEIS, EFA, HSBC, ING Luxembourg, Pictet, RBC Investor \& Treasury Services, Société Générale Bank \& Trust and $P w C$ companies created a Fundchain consortium to study the impact of blockchain on asset management. In the same year, 42 banks created a consortium in Japan to use the Ripple blockchain to make real-time payments. ISSN 1727-9313. HERALD OF KNUTE. 2019. 
In 2017 the Spanish bank Cecabank and Grant Thornton Company, together with other banks, established a blockchain consortium to develop money laundering counter-measures and improvement of customer identification procedures, covering 33\% of the Spanish banking sector [31].

The Dutch company Aegon, Swiss companies Swiss Re and Zurich, as well as the German Munich Re and Allianz have joined forces to create their own blockchain consortium - the Blockchain Insurance Industry Initiative. The purpose of this merger is to explore new technological capabilities that will enable insurance companies to improve the quality of services they provide and access of customers to them.

In 2014, the Blockchain Association of Ukraine was created, according to which, in $2017,32 \%$ of blockchain companies were founded in Ukraine. The founders of Ukrainian blockchain companies have previously worked in the fields of: finance, investment and trading (38\%); programming and development (38\%); cryptography and cryptocurrency (32\%); marketing and advertising (12\%). Most domestic blockchain companies (78\%) focus on both domestic and global markets, $16 \%$ focus solely on the external market and only one company focuses exclusively on the Ukrainian market [32]. The Bitfury group of companies is engaged in blockchain technology and is one of the largest infrastructure providers in the cryptocurrency ecosystem. Founded in 2011, Bitfury delivers solutions for businesses, governments, organizations and individuals to securely move assets across the blockchain. In 2017, a Memorandum of Cooperation was signed between Bitfury and the State Agency for Electronic Governance of Ukraine. Attic Lab and Bloqly should also be distinguished among Ukrainian blockchain companies [33].

Conclusion. It is determined that the financial ecosystem is a collection of traditional financial intermediaries, FinTech companies, FinTech startups, incubators, accelerators, regulators, business entities, individuals, public financial institutions, educational institutions which interact through the use of financial technology tools, that ensures maximum consumer inclusivity in the financial services market and transparency of public finances. The financial ecosystem is characterized by general and specific properties of the systems. The general properties include emergence, totality and heterogeneity; specific ones include adaptability, decentralization, customer orientation, inclusivity based on increasing consumer access to financial services and citizen participation in budgeting, as well as stability.

It is established that blockchains in the financial ecosystem can be classified by participants, level of centralization, generations and fields of application. The priorities of blockchain technology in ensuring the functioning of financial ecosystems are its use to counteract money laundering and terrorist financing, improve customer identification procedures, conclude smart contracts and improve the interaction of financial ecosystem entities. Intensifying the use of blockchain technologies in the financial sector will help transform centralized financial systems into decentralized financial 
ecosystems, which significantly increase the confidence of business entities and individuals in financial service providers and governments by increasing their openness, transparency and interoperability between its various participants. Further studies of blockchain technology are promising for its application in the activities of financial regulators.

\section{REFERENCES}

1. Mazaraki, A., Melnichenko, S., Duginets, G. et al. (2018). Ukrainian economy growth imperatives. Anatolii Mazaraki (Ed). Prague: Coretex CZ SE [in English].

2. Melnyk, T., Melnychenko, S., \& Reznikova, N. (2019). The conceptual framework for the operation of financial systems in the context of global structural transformations of business models of banking. Baltic Journal of Economic Studies. (Vol. 5), 4, 148-154. DOI: 10.30525/2256-0742/2019-5-4-148-154 [in English].

3. Lee, I., \& Shin, Y. (2018). Fintech: Ecosystem, Business Models, Investment Decisions, and Challenges. Business Horizons, 61 (1), 35-46. Retreived from https://ideas.repec.org/a/eee/bushor/v61y2018i1p35-46.html [in English].

4. Svensson, C., Udesen, J., \& Webb, J. (2019). Alliances in Financial Ecosystems: A Source of Organizational Legitimacy for Fintech Startups and Incumbents. Technology Innovation Management Review. (Vol. 9), 1, 20-32. Retreived from https://timreview.ca/article/1209 [in English].

5. Bose, S., Guo, D., \& Simpson, A. (2019). The financial ecosystem. Palgrave Studies in Impact Finance, 19-46. DOI: 10.1007/978-3-030-05624-7_2 [in English].

6. Pozsar, Z. (2013). Shadow banking and the global financial ecosystem. CEPR's policy portal. Retreived from https://voxeu.org/article/global-financial-ecosystem-0 [in English].

7. Katan, L., \& Ostrinina, V. (2018). Formuvannja finansovoi' ekosystemy bezgotivkovyh platezhiv v agrarnomu sektori Ukrai'ny [Formation of financial ecosystem of cashless payments in the agricultural sector of Ukraine]. Efektyvna ekonomika The efficient economy, 11. Retreived from http://www.economy.nayka.com.ua/ pdf/11_2018/15.pdf [in Ukrainian].

8. Netrebchuk, L., Kasjan, I., \& Shkurko, V. (2019). Transformacija dijal'nosti banku na bazi pobudovy ekosystemy [Transformation of bank activity on the basis of ecosystem structure]. Shidna Jevropa: ekonomika, biznes ta upravlinnja Eastern Europe: Economics, Business and Management. Vol. 1 (18), 330-335 [in Ukrainian].

9. Chen, Y., \& Bellavitis, C. (2019). Decentralized Finance: Blockchain Technology and the Quest for an Open Financial System. SSRN, 27. DOI: 10.2139/ ssrn.3418557 [in English].

10. John E., Mulhall (2018). Blockchain And The Future Of Finance. Forbes. Retreived from https://www.forbes.com/sites/kpmg/2018/09/11/blockchain-andthe-future-of-finance/\#2d80455620f8 [in English].

11. Baranov, O. (2018). Internet rechej (IoT) i blokchejn [Internet of Things (IoT) and blockchain]. Informacija i pravo - Information and law, 1 (24), 59-71. Retreived from http://ippi.org.ua/sites/default/files/8_7.pdf [in Ukrainian].

12. Strategija Nacional'nogo banku Ukrai'ny [Strategy of the National Bank of Ukraine] (2018). Nacional'nyj bank Ukrai'ny - National Bank of Ukraine. Retreived from https://bank.gov.ua/control/uk/publish/article?art_id=65990001\&cat_id=55838 [in Ukrainian].

ISSN 1727-9313. HERALD OF KNUTE. 2019. 
13. Popkova, E. (2019). Growth Poles of the Global Economy: Emergence, Changes and Future Perspectives. Springer. (Vol. 1). 1413 p. Retreived from https://books.google.com.ua/books?id=FjinDwAAQBAJ\&pg=PA128\&lpg=PA 128\&dq=financial+ecosystem\&source=bl\&ots=VLZLABR9-3\&sig=ACfU3U1yMjzLz$1373523 \mathrm{KtqY} P C A 0 K f H Z Q \& h l=u k \& s a=X \& v e d=2 a h U K E w i 2 i j j S n t r l A h V k 14 s K$ HfZqBv44bhDoATAFegQICRAB $\# \mathrm{v}=$ onepage $\& \mathrm{q}=$ financial $\% 20$ ecosystem \&f=false [in English].

14. McWaters, J. (2018). The New Physics of Financial Services. World Economic Forum, 167 . Retreived from http://www3.weforum.org/docs/ WEF_New_ Physics_of_Financial_Services.pdf [in English].

15. Deep Shift - Technology Tipping Points and Societal Impact: Survey Report (2015). World Economic Forum, 44. Retreived from http://www3.weforum.org/ docs/WEF_GAC15_Technological_Tipping_Points_report_2015.pdf [in English].

16. Venture Pulse Q1 2019: Global analysis of venture funding. KPMG. 2019. 103 p. Retreived from https://assets.kpmg/content/dam/kpmg/xx/pdf/2019/04/venturepulse-q1-2019.pdf [in English].

17. 19 Phenomenal Fintech in 2018: Insights by KPMG (2019). KPMG. Retreived from https://www.sepaforcorporates.com/payments-news-2/19-phenomenalfintech-in-2018-insights-by-kpmg [in English].

18. The Pulse of FinTech Q4 2016: Global analysis of investment in fintech (2017). $K P M G$, 97. Retreived from https://assets.kpmg/content/dam/kpmg/xx/pdf/2017/02/ pulse-of-fintech-q4-2016.pdf [in English].

19. Issledovanie: Kitaj investiruet v blokchejn do $\$ 2 \mathrm{mlrd}$. [Study: China invests in blockchain up to $\$ 2$ billion]. (2019). Let know. Retreived from https://letknow.news/ news/issledovanie-kitay-investiruet-v-blokcheyn-do-2-mlrd-32693.html [in Russian].

20. Amerikanskie tamozhenniki otsledjat import nefti s pomoshh'ju blokchejna [US customs officials will track oil import using blockchain] (20190. Let know. Retreived from https://letknow.news/news/amerikanskie-tamozhenniki-otsledyatimport-nefti-s-pomoshchyu-blokcheyna-32579.html [in Russian].

21. Chislo vakansij v sfere blokchejna vyroslo na $26 \%$ [The number of vacancies in the blockchain sector increased by 26\%] (2019). Let know. Retreived from https://letknow.news/news/chislo-vakansiy-v-sfere-blokcheyna-vyroslo-na-2632614.html [in Russian].

22. Volosovych, S. (2017). Dominanty tehnologichnyh innovacij u finansovij sferi [Dominants of technological innovation in the financial sector]. Ekonomichnyj visnyk universytetu - University Economic Herald. (Vol. 33 (1), 15-22. Retreived from http://nbuv.gov.ua/UJRN/ecvu_2017_33\%281\%29_4 [in Ukrainian].

23. Volosovych, S., \& Fomina, O. (2018). Tehnologichni innovacii' na strahovomu rynku [Technological innovations in the insurance market]. Visnyk Kyi'vs 'kogo nacional'nogo torgovel'no-ekonomichnogo universytetu - Herald of the Kyiv National University of Trade and Economics, 5, 124-137[in Ukrainian].

24. Mazaraki, A., \& Volosovych, S. (2019). Dominanty FINTECH na rynku platizhnyh poslug [FINTECH's dominants in the payment services market]. Zovnishnja torgivlja: ekonomika, finansy, pravo - Foreing trade: economics, finance, law, 2, 100-118 [in Ukrainian].

25. Volosovych, S., Vasylenko, A., \& Chubajevs'kyj, V. (2019). Finansovi tehnologii' podatkovogo administruvannja [Financial technologies of tax administration]. Visnyk Kyi'vs' 'kogo nacional'nogo torgovel'no-ekonomichnogo universytetu Herald of the Kyiv National University of Trade and Economics, 4, 5-15 [in Ukrainian]. 
26. V g. Shjen'chzhjen' vypisano bolee $10 \mathrm{mln}$ jelektronnyh schetov s pomoshh'ju blokchejn-tehnologii [More than 10 million electronic invoices have been issued in Shenzhen city using blockchain technology] (2019). Russian.News.Cn. Retreived from http://russian.news.cn/2019-11/01/c_138520837.htm [in Russian].

27. Understanding the Decentralized Finance Ecosystem (2019). Altcoin Buzz. Retreived from https://www.altcoinbuzz.io/bitcoin-and-crypto-guide/understandingthe-decentralized-finance-ecosystem-part-1 [in English].

28. Athawasya, A. (2019). Nasdaq bullish on crypto and blockchain as stock giant adds Decentralised Finance Index. AMB Crypto. Retreived from https://eng.ambcrypto.com/ nasdaq-bullish-on-crypto-and-blockchain-as-stock-giant-adds-decentralisedfinance-index [in English].

29. Forbes opublikuvav top-50 kompanij, jaki vykorystovujut' blokchejn (2019). Mind Ukraine. Retreived from https://mind.ua/news/20196159-forbesopublikuvav-top-50-kompanij-yaki-vikoristovuyut-blokchejn [in English].

30. WTO report: blockchains could add USD 1 th to world trade by 2030 (2018). The Paypers. Retreived from https://thepaypers.com/news/wto-report-blockchainscould-add-usd-1-tln-to-world-trade-by-2030--776172 [in English].

31. Ispanskie banki sozdali blokchejn-konsorcium [Spanish banks set up blockchain consortium] (2017). Plas - Plus. Retreived from https://www.plusworld.ru/ daily/tehnologii/ispanskie-banki-sozdali-blokchejn-konsortsium-2 [in Russian].

32. Matkovs'ka, D. (2019). Asociacija Blokchejn Ukrai'ny vypustyla Ogljad blokchejn industrii' [The Blockchain Association of Ukraine has released the Blockchain Industry Review]. Blokchejn Ukrai'ny - Blockchain of Ukraine. Retreived from https://bau.ai/\%D0\%B1\%D0\%B5\%D0\%B7-\%D1\%80\%D1\%83\%D0\%B1\% D1\%80\%D0\%B8\%D0\%BA\%D0\%B8-uk/\%D0\%B0\%D1\%81\%D0\%BE\%D1\%86\% D1\%96\%D0\%B0\%D1\%86\%D1\%96\%D1\%8F-\%D0\%B2\%D0\%B8\%D0\%BF\% D1\%83\%D1\%81\%D1\%82\%D0\%B8\%D0\%BB\%D0\%B0-\%D0\%BE\%D0\%B3\% D0\%BB\%D1\%8F\%D0\%B4-\%D0\%B1\%D0\%BB\%D0\%BE\%D0\%BA\%D1\% $87 \% \mathrm{D} 0 \% \mathrm{~B} 5 \% \mathrm{D} 0 \% \mathrm{~B} 9 \% \mathrm{D} 0 \% \mathrm{BD}-\% \mathrm{D} 1 \% 96$ [in Ukrainian].

33. "Poperedu planety vsijei'": jaki kompanii' zajmajut'sja blokchejnom v Ukrai'ni ["Ahead of the whole Planet": what companies are doing blockchain in Ukraine]. (2019). Ekonomichna pravda. Specprojekt "FinTeh" - Economic truth. "FinTech" Special Project. Retreived from https://www.epravda.com.ua/projects/fintech/ 2019/10/9/652378 [in Ukrainian].

The article submitted to editor's office on 18.11.2019.

Волосович С., Баранюк Ю. Технологія блокчейн у фінансовій екосистемі.

Постановка проблеми. Розвиток технологічних інновацій та економіки споживання започаткував формування фінансових екосистем, які тісно пов'язані з різноманітними інструментами фінансових технологій. Одним з інструментів фінансових технологій є технологія блокчейн.

Аналіз останніх досліджень і публікацій свідчить, щуо існування фінансових екосистем базується на технологіях, важливим інструментом яких є блокчейн.

Метою статті є визначення пріоритетів застосування технології блокчейн у забезпеченні функиіонування фінансових екосистем.

Матеріали та методи. Теоретичним та методологічним підгрунтям для написання статті стали праці вітчизняних та зарубіжних науковичів. Дослідження проведено із застосуванням методів теоретичного узагальнення, порівняльного аналізу та синтезу.

ISSN 1727-9313. HERALD OF KNUTE. 2019. 
Результати дослідження. У розумінні фінансових екосистем існують інституційний, функціональний та галузевий підходи. Фінансовій екосистемі притаманні загальні та специфічні властивості систем. Загальними властивостями фінансової екосистеми є емерджентність, гетерогенність та сукупність. До специфічних властивостей належать: технологічність, децентралізація, клієнтоорієнтованість, інклюзивність $і$ стабільність. Фінансова екосистема є сукупністю традиційних фінансових посередників, FinTесh-компаній, FinTech-cтартапів, інкубаторів, акселераторів, регуляторів, суб'єктів господарювання, фізичних осіб, державних фінансових інститутів, освітніх закладів, які взаємодіють на основі застосування інструментів фінансових технологій, щчо забезпечує максимальну інклюзивність споживачів на ринку фінансових послуг та прозорість державних фінансів. Блокчейни у фінансовій екосистемі можна класифікувати за учасниками, рівнем централізації, поколіннями, сферами застосування.

Висновки. Активізація застосування блокчейн-технологій у фінансовій сфері сприятиме трансформації ичентралізованих фінансових систем у децентралізовані фінансові екосистеми, в яких значно підвищується рівень довіри суб'єктів господарювання та фізичних осіб до оферентів фінансових послуг та урядів завдяки зростанню їх відкритості, прозорості та сумісності між їі різними учасниками.

Ключові слова: фінансова екосистема, фінансові технології, технологія блокчейн, смарт-контракт. 